\title{
PEMANFAATAN AIR REBUSAN UMBI KUNING DAN UNGU SEBAGAI MEDIA ALTERNATIF PERTUMBUHAN Escherichia coli DAN Staphylococcus aureus
}

\author{
Khaerunnisa, Rismaya ${ }^{1}$; Kurniati, lis ${ }^{1}$; Nurhayati, Dewi ${ }^{1}$; Dermawan, Asep ${ }^{1}$ \\ 1Jurusan Analis Kesehatan Poltekkes Kemenkes Bandung \\ Email: rismaya.kh1@gmail.com
}

\begin{abstract}
ABSTRAK
Penggunaan media dalam cabang ilmu biologi yaitu mikrobiologi sangat penting untuk isolasi dan pertumbuhan bakteri. Mahalnya media pertumbuhan bakteri mendorong para peneliti untuk membuat media pertumbuhan bakteri yang berasal dari alam dengan biaya yang lebih ekonomis. Penelitian ini bertujuan untuk menentukan adanya pertumbuahn jumlah bakteri pada media alternatif umbi kuning dan umbi ungu. Desain dalam penelitian yang digunakan adalah Perbandingan Kelompok Statis (statis Group Comparation). Kelompok eksperimen dalam penelitian ini adalah Escherichia coli dan Staphylococcus aureus yang ditanamkan pada media alternatif umbi kuning dan umbi ungu yang dibandingkan jumlah pertumbuhan bakteri terhadap kontrol yaitu media nutrient agar. Bakteri di isolasikan dengan metode pour plate dan di inkubasi pada suhu $37{ }^{\circ} \mathrm{C}$ selama 24 jam. Hasil penelitian menunjukan media umbi kuning merupakan media alternatif yang paling baik untuk pertumbuhan jumlah bakteri, hal ini ditunjukan pada pertumbuhan Escherichia coli didapat jumlah bakteri yang paling tinggi sebesar $284,83 \times 10^{5}$ sedangkan pertumbuhan Staphylococcus aureus didapat jumlah bakteri yang paling tinggi sebesar $56,5 \times 10^{5}$.
\end{abstract}

Kata Kunci: Media, bakteri, nutrien agar, umbi kuning dan umbi ungu

\begin{abstract}
In a part of biology named microbiology, the use of growth medium is very important to grow, isolate, calculate the amout, and test the physical properties of bacteria so that bacteria can be identified. The high cost of bacteria growth medium encourage researchers to creaye a medium for bacteria to growth originating from nature with more economical cost. This study aims to determine the number of bacteria witch growth on alternative medium yellow sweet potato and purple sweet potato. The method that usedin this study is Statistic Comparation Group. The experimental group used in this study were Escherichia coli and Staphylococcus aureus which were implanted in alternative medium yellow sweet potato and purple sweet potato compared to the number of bacteria growth on the control in Nutrient Agar medium. Bacteria were isolated by pour plate method and incubated at $37^{\circ} \mathrm{C}$ for 24 hours. The results showed that yellow sweet potato was the best alternative medium for the growth of bacteria in amount, this was show by the growth of Escherichia coli, the highest number of bacteria amount is $284,83 \times 10^{5}$, while the highest growth amouth of Staphylococcus aureus was $56,5 \times 10^{5}$.
\end{abstract}

Keywords: Medium, bacteria, Nutrient Agar, yellow sweet potato, purple sweet potato 


\section{PENDAHULUAN}

Penggunaan media dalam cabang ilmu biologi yaitu mikrobiologi sangat penting untuk menumbuhkan, isolasi, perhitungan jumlah, dan pengujian sifat-sifat fisik bakteri sehingga suatu bakteri dapat diidentifikasi. ${ }^{(1)}$ Nutrisi yang dibutuhkan mikroorganisme untuk pertumbuhannya meliputi karbon, nitrogen, unsur non logam seperti fosfor, unsur logam seperti $\mathrm{Ca}, \mathrm{Na}$, Fe, vitamin, air, dan energi. Untuk itu, media pertumbuhan bakteri harus memenuhi syarat nutrisi yang dibutuhkan. $^{(2)}$

Nutrient Agar (NA) adalah salah satu contoh media instan yang sering digunakan untuk isolasi dan pertumbuhan bakteri. Harga Nutrient Agar yang cukup mahal yaitu $\pm R p$ 1.500.000,- untuk setiap 500 gram mendorong para peneliti untuk membuat media pertumbuhan bakteri yang berasal dari alam dengan biaya yang lebih ekonomis. Bahan yang digunakan harus mengandung nutrisi yang dibutuhkan untuk pertumbuhan bakteri seperti dari bahan-bahan yang kaya akan karbohidrat dan protein. ${ }^{(1)}$

Pemanfaatan sumber daya alam lain seperti beberapa jenis umbi yang mengandung karbohidrat cukup tinggi juga telah digunakan sebagai media pertumbuhan bakteri. Penelitian tersebut berhasil dilakukan oleh Anisah (2015) yang menumbuhkan bakteri gram positif dan bakteri gram negatif dengan menggunakan media yang berasal dari umbi garut, umbi gembili, dan umbi ganyong. ${ }^{(3)}$ Jenis umbi lain yang memiliki potensi yang sama adalah umbi kuning dan umbi ungu.

Umbi kuning dan umbi ungu mengandung serat pangan alami yang tinggi yaitu oligosakarida. Oligosakarida merupakan bagian dari karbohidrat yang dapat dijadikan sumber makanan untuk peningkatan jumlah bakteri.
Rafinosa merupakan jenis oligosakarida yang terdapat dalam ubi jalar. ${ }^{(4)}$

Rafinosa merupakan trisakarida yang terdiri dari monumer fruktosa, glukosa dan galaktosa. Oligosakarida dari kelompok rafinosa bersifat fungsional karena tidak dapat dicerna oleh enzim-enzim pencernaan manusia, sehingga mampu untuk meningkatkan pertumbuhan jumlah bakteri mikroflora normal yang terdapat didalam usus. ${ }^{(5)}$

Penelitian ini bertujuan untuk mengkaji berbagai macam media alternatif untuk pertumbuhan Escherichia coli dan Staphylococcus aureus menggunakan berbagai sumber karbohidrat yang berbeda yaitu umbi kuning dan umbi ungu.

\section{METODE}

Penelitian ini menggunakan jenis penelitian quasi eksperimen dengan metode Perbandingan Kelompok Statis (statis Group Comparation). Dalam penelitian ini kelompok eksperimen Escherichia coli dan Staphylococcus aureus ditanamkan pada media alternatif umbi kuning dan umbi ungu. Hasil pengamatan ini kemudian dibandingkan dengan hasil pengamatan pada kelompok kontrol yakni Escherichia coli dan Staphylococcus aureus ditanamkan pada Nutrient Agar.

Penelitian ini dilakukan di Laboratorium Mikrobiologi Kampus Analis Kesehatan Poltekkes Bandung pada bulan Maret - Mei 2019. Pelaksanaan penelitian diawali dengan merebus umbi kuning dan umbi ungu sebanyak $300 \mathrm{gr}$ dalam $1000 \mathrm{ml}$ aquadest selama 1 jam, kemudian filtrat rebusan yang diperoleh ditambahkan kembali aquadest sampai volume kembali $1000 \mathrm{ml}$, kemudian dilanjutkan dengan membuat media dengan menambahkan dextrose sebanyak 10 gr dan agar (Swallow) 15 gr kedalam 
air rebusan, kemudian media disterilisasi agar terbebas dari mikroba. Selanjutnya Escherichia coli dan Staphylococcus aureus diencerkan sebanyak $10^{-5}$ dan diinokulasikan pada media dengan metode pour plate dan dihitung total jumlah bakteri dengan metode TPC (Total Plate Count) secara langsung.

Teknik pengumpulan data dalam penelitian ini adalah data primer yang diperoleh dari pemeriksaan Angka Lempeng Total dari media alternatif umbi kuning dan umbi ungu serta media Nutrient Agar, kemudian data ditampilkan dalam bentuk tabel. Setelah itu untuk memperoleh perbedaan jumlah bakteri, data yang diperoleh diolah menggunakan uji statistik yaitu ANOVA untuk melihat adanya perbedaan pertumbuhan bakteri pada setiap media.

\section{HASIL}

Setelah dilakukan penelitian pemanfaatan air rebusan umbi kuning dan umbi ungu sebagai media alternatif pertumbuhan Escherichia coli dan Staphylococcus aureus didapat hasil sebagai berikut:
Tabel 1 Hasil Pertumbuhan Escherichia coli dan Staphylococcus aureus

\begin{tabular}{|c|c|c|c|}
\hline \multirow{2}{*}{$\begin{array}{l}\text { Jenis } \\
\text { media }\end{array}$} & \multirow[b]{2}{*}{ Ulangan } & \multicolumn{2}{|c|}{ Jumlah Bakteri } \\
\hline & & $\begin{array}{c}\text { Escherichia } \\
\text { coli }\end{array}$ & $\begin{array}{c}\text { Staphylococcus } \\
\text { aureus }\end{array}$ \\
\hline $\begin{array}{l}\text { Nutrien } \\
\text { Agar }\end{array}$ & (1) & 146 & 300 \\
\hline & (2) & 151 & 263 \\
\hline & (3) & 300 & 157 \\
\hline & (4) & 152 & 120 \\
\hline & (5) & 154 & 299 \\
\hline & (6) & 125 & 106 \\
\hline $\begin{array}{c}\text { Umbi } \\
\text { Kuning }\end{array}$ & (1) & 290 & 83 \\
\hline & (2) & 281 & 30 \\
\hline & (3) & 300 & 52 \\
\hline & (4) & 300 & 34 \\
\hline & (5) & 243 & 101 \\
\hline & (6) & 295 & 39 \\
\hline $\begin{array}{l}\text { Umbi } \\
\text { Ungu }\end{array}$ & (1) & 115 & 30 \\
\hline & (2) & 108 & 39 \\
\hline & (3) & 138 & 60 \\
\hline & (4) & 150 & 30 \\
\hline & (5) & 261 & 67 \\
\hline & (6) & 267 & 46 \\
\hline
\end{tabular}

\section{Jumlah Koloni Escherichia coli dan Staphylococcus aureus}

Variabel yang diamati adalah jumlah bakteri yang tumbuh pada media nutrien agar, umbi kuning, umbi ungu yang diinkubasi pada suhu $37^{\circ} \mathrm{C}$ selama 24 jam. Hasil perhitungan jumlah bakteri Escherichia coli dan Staphylococcus aureus pada media nutrien agar, umbi kuning, dan umbi ungu disajikan pada tabel 1 .

Pada hasil uji normalitas menunjukan data yang terdistribusi nomal pada pemanfaatan air rebusan umbi kuning dan umbi ungu sebagai media alternatif pertumbuhan Escherichia coli dan Staphylococcus aureus. Hal ini ditunjukan dengan menggunakan uji normalitas kolmogorof-smirnov yang menunjukan nilai sig. 0,051. Sehingga pengujian bisa dilanjutkan dengan menggunakan uji ANOVA. 
Pada hasil analisis ANOVA menunjukan bahwa tidak terdapat perbedaan pada jumlah bakteri yang ditanamkan pada media Nutrien agar, media alternatif umbi kuning, dan media alternatif umbi ungu. Hasil interaksi antara pemanfaatan media alternatif umbi kuning, umbi ungu dan media Nutrien Agar terhadap jumlah Bakteri memberikan nilai $\mathrm{p}>\alpha$ yaitu $0,124>0,05$ maka $\mathrm{H}_{0}$ diterima. Kesimpulannya tidak terdapat perbedaan jumlah bakteri yang ditanamkan pada media Nutrien Agar, media alternatif umbi kuning, dan media alternatif umbi ungu.

\section{Media Alternatif yang paling bagus untuk pertumbuhan bakteri}

Media alternatif yang lebih bagus untuk pertumbuhan bakteri adalah media alternatif umbi kuning. Hal ini ditunjukan pada hasil uji post hoc menghasilkan nilai means diference yang besar yaitu 60,67 jika dibandingkan dengan umbi ungu.

\section{PEMBAHASAN}

\section{Identifikasi Makroskopis Escherichia coli dan Staphylococcus aureus}

Identifikasi secara makroskopis bertujuan untuk mengetahui bentuk koloni, warna koloni, dan bentuk pewarnaan koloni. Identifikasi ini dilakukan dengan menggunakan dua jenis strain bakteri yang berbeda. Berdasarkan hasil pengamatan pada isolat uji untuk tersangka Escherichia coli, koloni menunjukan warna hijau metalik, berbentuk bulat, cembung, dengan tepian bening. Pada isolat uji tersangka Staphylococcus aureus, koloni menunjukan warna abu-abu hingga kuningan keemasan, berbentuk bulat, dengan tepian berwarna kuning. Menurut Dwijoseputro, pengamatan makroskopis morfologi koloni meliputi bentuk koloni (dilihat dari atas), Permukaan koloni (dilihat dari samping), tepi koloni (dilihat dari atas), dan warna koloni bakteri. ${ }^{(6)}$

\section{Identifikasi Mikroskopis Escherichia coli dan Staphylococcus aureus.}

Identifikasi mikroskopis dilakukan dengan pewarnaan gram untuk isolat uji tersangka Escherichia coli serta untuk isolat uji tersangka Staphylococcus aureus dilakukan dengan pewarnaan gram dan uji Serologi. Escherichia coli dapat tumbuh pada suhu $20-40 \quad{ }^{\circ} \mathrm{C}$ dengan suhu optimum $37{ }^{\circ} \mathrm{C} \cdot{ }^{(7)} \quad$ Staphylococcus aureus dapat tumbuh pada suhu 4,6-46 ${ }^{\circ} \mathrm{C}$ dengan suhu optimum $37{ }^{\circ} \mathrm{C} .{ }^{(8)}$ Hasil identifikasi dari isolat uji tersangka Escherichia coli menunjukan hasil negatif dari pewarnaan gram dan untuk hasil identifikasi dari isolat uji tersangka Staphylococcus aureus menunjukan hasil positif dari pewarnaan gram.

\section{Pewarnaan Gram}

Pewarnaan Gram merupakan identifikasi awal untuk mengetahui jenis Gram dari isolat bakteri yang merupakan penentu karakter dari isolat berdasarkan perbedaan struktur dinding sel bakteri, sehingga menyebabkan perbedaan reaksi dalam permeabilitas zat warna dan penambahan larutan pencuci. Pada hasil dari pewarnaan Gram ini bakteri Gram negatif berwarna merah sedangkan untuk bakteri Gram positif berwarna ungu. ${ }^{(9)}$

Pewarnaan Gram pada isolat uji tersangka Escherichia coli menunjukan hasil Gram negatif batang dan pada isolat uji tersangka Staphylococcus aureus menunjukan hasil Gram positif kokus. Dinding sel bakteri Gram positif terdiri dari lapisan peptidoglikan yang tebal sedangkan dinding sel bakteri gram negatif mempunyai kandungan lipid yang tebal. Ketika ditambahkan pewarnaan kristal violet maka dinding sel bakteri Gram positif maupun gram negatif akan menyerap zat warna tersebut, namun ketika diberi alkohol, kristal violet pada Gram negatif akan luntur disebabkan struktur dinding 
selnya yang sebagian besar tersusun oleh lipid, sehingga ketika diberi safranin (zat warna kedua) dinding sel bakteri Gram negatif akan menyerap kembali sehingga hasil pewarnaan Gram negatif akan berwarna merah, sedangkan bakteri Gram positif akan tetap berwarna ungu walaupun diberi zat warna kedua, karena dinding selnya tersusun oleh lapisan peptidoglikan yang tebal sehingga tidak dapat dicuci oleh alkohol. Hal tersebut memberikan hasil pewarnaan ungu pada bakteri Gram Positif. ${ }^{(10)}$

\section{Uji Biokimia}

Uji Biokimia digunakan untuk menentukan genus atau spesies dari bakteri. Uji ini dilakukan untuk mengetahui kemampuan bakteri dalam mereaksikan senyawa kimia yang hasilnya dapat dikaitkan dengan sifat bakteri itu sendiri. Media yang digunakan dalam uji biokimia ini adalah Indol, Metil Merah, Voges-Proskauer, dan Simon Sitrat. Identifikasi yang didapat dalam penelitian ini menunjukan hasil positif pada Indol dan Metil Merah serta menunjukan hasil negatif pada Voges-Proskauer, dan Simon Sitrat.

Hasil positif pada Indol ditandai dengan terbentuknya cincin warna merah pada permukaan media setelah ditambahkan reagen Kovac's yang menunjukan bahwa bakteri mampu memecah asam amino triptofan. Hasil positif pada Metil Merah ditandai dengan adanya warna merah pada media setelah ditambahkan reagen Metil Merah yang menunjukan kemampuan bakteri dalam memfermentasi asam. Pada media Voges-Proskauer ketika ditambahkan reagen Baritts $A$ dan Barits $B$ menunjukan hasil yang negatif, karena media tidak berubah menjadi warna merah kehitaman. Sedangkan pada media Simon Sitrat didapat hasil negatif ditandai dengan tidak berubahnya warna media menjadi biru. Hal ini menandakan bahwa bakteri tersebut tidak menggunakan sitrat sebagai karbonnya. ${ }^{(11)}$ Berdasarkan hasil uji biokimia yang telah dilakukan maka isolat bakteri uji adalah Escherichia coli.

\section{Uji Serologi}

Uji serologi bertujuan untuk mengetahui kemampuan bakteri untuk menghasilkan enzim koagulase. Uji ini dilakukan untuk mengidentifikasi dugaan Staphylococcus aureus. Koagulase merupakan protein ekstraseluler yang dihasilkan oleh Staphylococcus aureus yang dapat menggumpalkan plasma dengan bantuan faktor yang terdapat dalam serum. Oleh karena itu peran koagulase yang dihasilkan oleh Staphylococcus aureus dapat digunakan sebagai sarana diagnostik. ${ }^{(12)}$ Pada hasil identifikasi isolat uji menunjukan hasil positif ketika dilakukan uji serologi. Hal ini menandakan bahwa isolat uji adalah Staphylococcus aureus.

\section{Identifikasi Escherichia coli}

Identifikasi bakteri Escherichia coli dapat diketahui dengan melihat bentuk sel serta hasil dari uji biokimia yang ditemukan. ${ }^{(13)}$ Isolat uji memiliki bentuk sel batang pendek, gram negatif, dan ketika dilakukan uji biokimia dengan menggunakan media INVIC memberikan hasil +, +, -, - yang menandakan bahwa bakteri uji merupakan Escherichia coli.

\section{Tabel 2 Hasil uji identifikasi Escherichia coli}

\begin{tabular}{cc}
\hline UJI & HASIL \\
\hline Uji Mikroskopis & Gram negatif batang \\
\hline Uji Biokimia & Hasil \\
\hline Indol & Positif \\
Metil Red & Positif \\
Voges-Proskauer & Negatif \\
Simon Sitrat & Negatif \\
\hline
\end{tabular}


Pada perlakuan menggunakan bakteri Escherichia coli sebagai bakteri uji pada pemanfaatan media alternatif umbi kuning dan umbi ungu didapatkan hasil media umbi kuning menunjukan hasil jumlah koloni yang tertinggi yaitu dengan rata-rata jumlah koloni bakteri $284,83 \times 10^{5} \mathrm{CFU} / \mathrm{ml}$ jika dibandingkan dengan media alternatif umbi ungu dengan rata-rata jumlah koloni bakteri $173,16 \times 10^{5} \mathrm{CFU} / \mathrm{ml}$ terhadap pertumbuhan jumlah koloni Escherichia coli, sedangkan untuk media nutrien agar (kontrol) rata-rata jumlah koloni 171,33 x 105 CFU/ml.

\section{Identifikasi Staphylococcus aureus}

Identifikasi untuk membedakan Staphylococcus aureus dengan Staphylococcus lainnya didasarkan pada kriteria fenotip yang meliputi bentuk sel dan susunanya, uji koagulase, serta adanya fermentasi manitol pada media MSA. ${ }^{(14)}$ Isolat uji memiliki bentuk sel coccus dengan susunan bergerombol seperti buah anggur, Gram positif, koagulase positif, dan ketika diisolasikan pada media MSA menunjukan adanya fermentasi manitol, yang menandakan bahwa bakteri uji merupakan Staphylococcus aureus.

Pada perlakuan menggunakan bakteri Staphylococcus aureus sebagai bakteri uji pada pemanfaatan media alternatif umbi kuning dan umbi ungu didapatkan il media umbi kuning menunjukan hasil jumlah koloni yang tertinggi yaitu dengan rata-rata jumlah koloni bakteri $56,5 \times 10^{5} \mathrm{CFU} / \mathrm{ml}$ jika dibandingkan dengan media alternatif umbi ungu dengan rata-rata jumlah koloni bakteri 45,33 x $10^{5} \mathrm{CFU} / \mathrm{ml}$ terhadap pertumbuhan jumlah koloni Staphylococcus aureus, sedangkan untuk media nutrien agar (kontrol) ratarata jumlah koloni $207,5 \times 10^{5} \mathrm{CFU} / \mathrm{ml}$.

Hasil pada pemanfaatan media alternatif dari umbi kuning dan umbi ungu menunjukan hasil jumlah koloni yang berbeda baik media alternatif yang ditanami bakteri Escherichia coli maupun media alternatif yang ditanami Staphylococcus aureus. Perbedaan tersebut dipengaruhi oleh kandungan nutrisi dan tingkat kematangan dari umbi pada masin-masing media. Berikut tabel perbandingan nutrisi pada masing-masing umbi. ${ }^{(15)}$

Tabel 3 Kandungan Gizi Umbi kuning dan Ungu

\begin{tabular}{cccc}
\hline \multirow{2}{*}{$\begin{array}{c}\text { Kandungan } \\
\text { Gizi }\end{array}$} & Satuan & \multicolumn{2}{c}{$\begin{array}{c}\text { Jumlah } \\
\text { Kandungan } \\
\text { Gizi }\end{array}$} \\
\cline { 2 - 4 } & & $\begin{array}{c}\text { Umbi } \\
\text { kuning }\end{array}$ & $\begin{array}{c}\text { Umbi } \\
\text { Ungu }\end{array}$ \\
\hline Energi & Kkal & 136 & 123 \\
Protein & $\mathrm{G}$ & 1,1 & 1,8 \\
Lemak & $\mathrm{G}$ & 0,4 & 0,7 \\
Karbohidrat & $\mathrm{G}$ & 32,3 & 27,9 \\
Natrium & $\mathrm{Mg}$ & 5 & 77 \\
Kalsium & $\mathrm{Mg}$ & 57 & 30 \\
Fosfor & $\mathrm{Mg}$ & 52 & 49 \\
Besi & $\mathrm{Mg}$ & 0,7 & 0,7 \\
Vitamin B & $\mathrm{Mg}$ & 900 & 0,7 \\
Vitamin C & $\mathrm{Mg}$ & 0,04 & 22 \\
Air & $\mathrm{G}$ & 70,9 & 62,9 \\
\hline Sumber: Direktorat Gizi & Departemen \\
Republik Indonesi (1995) & \multicolumn{2}{c}{}
\end{tabular}

Berdasarkan tabel 3, umbi kuning memiliki kadar nutrisi yang rendah namun media dari umbi kuning menunjukan hasil yang lebih baik untuk pertumbuhan jumlah koloni bakteri. Hal tersebut dikarenakan kandungan karbohidrat dalam umbi kuning lebih tinggi dibandingkan umbi ungu sehingga memberikan hasil yang lebih baik terhadap pertumbuhan jumlah koloni. Karbohidrat yang terdapat dalam umbi ini adalah rafinosa. rafinosa ini merupakan trisakarida yang terdiri dari monumer fruktosa, glukosa dan galaktosa yang dijadikan sumber energi untuk meningkatkan jumlah pertumbuhan bakteri. ${ }^{(16)}$ Menurut Maulana perbedaan pertumbuhan jumlah bakteri dipengaruhi oleh kadar karbohidrat yang terdapat pada umbi itu sendiri. Kadar karbohidrat juga dapat dipengaruhi dari masa penyimpanan yang berupa peningkatan gula pereduksi. ${ }^{(17)}$ 
Apabila dilihat dari ukuran koloni pada media alternatif menunjukan ukuran koloni yang kecil-kecil jika dibandingkan dengan nutrien agar yang menghasilkan ukuran koloni yang lebih besar dan mudah untuk diamati. Hal ini dikarenakan kandungan protein pada media nutrien agar lebih banyak dibandingkan dengan kandungan protein pada media alternatif. Menurut fardiaz bakteri akan menghidrolisis protein untuk memperoleh energi yang diperlukan untuk pertumbuhan ukuran koloni bakteri. ${ }^{(18)}$

Proses Hidrolisis protein dilakukan karena molekul protein terlampau besar untuk dapat masuk melalui membran sel bakteri, sehingga bakteri mengekskresikan enzim protease yang menghidrolisis protein menjadi peptide yang lebih sederhana. Kemudian peptide yang terbentuk dengan bantuan peptidase diubah menjadi asam amino, sehingga asam amino yang terbentuk dapat masuk kedalam sel bakteri. Didalam sel bakteri Asam amino yang terbentuk dikatalisis oleh enzim asam laktat dehidrogenase dan direduksi oleh NADH untuk menghasilkan energi, sehingga dapat digunakan untuk pertumbuhan ukuran koloni. ${ }^{(18)}$

\section{SIMPULAN}

Berdasarkan hasil penelitian dan pembahasan yang berkaitan dengan pemanfaatan air rebusan umbi kuning dan ungu sebagai media alternatif pertumbuhan Escherichia coli dan Staphylococcus aureus, maka dapat ditarik kesimpulan bahwa media umbi kuning dan umbi ungu dapat digunakan sebagai media alternatif dalam pertumbuhan jumlah bakteri. Pada hasil penelitian menunjukan tidak terdapat perbedaan pertumbuhan jumlah bakteri Escherichia coli maupun Staphylococcus aureus yang ditanam pada media Nutrien agar, media alternatif umbi ungu dan umbi kuning. Serta media paling baik yang dapat digunakan sebagai pertumbuhan jumlah koloni adalah pada media alternatif umbi kuning.

\section{DAFTAR RUJUKAN}

1. Hiranya, Meganada, Sukini, Yodong. 2017. Mikrobiologi Keperawatan Gigi. Pusat pendidikan sumber daya manusia kesehatan. Jakarta

2. Sumarsih, Sri. 2003. Mikrobiologi Dasar. Fakultas pertanian upn. Yogyakarta

3. Anisah. 2015. Media Alternatif Untuk Pertumbuhan Bakteri Menggunakan Sumber Karbohidrat yang Berbeda. Surakarta.

4. El Husna, Nida, Melly Novita, Syarifah Rohaya. 2013. Kandungan Antosianin dan Aktivitas Antioksidan Ubi Jalar Ungu Segar dan Produk Olahan. Banda Aceh: Agritech

5. Susanti, Irma, Eddy Sapto Hartanto, Ning Ima Arie Wardayanie. 2012. Studi Kandungan Oligosakarida Berbagai Jenis Ubi Jalar dan Aplikasinya Sebagai Minuman Fungsional. Bogor: Warta IHP

6. Waluyo, L,. 2007. Mikrobiologi Umum. UPT Penerbit UMM. Malang.

7. Indah, Lies Sutiknowati. 2016. Bioindikator Pencemar Bakteri Escherichia coli. Malang

8. Krishna, Amalia Dewi. 2013. Isolasi, Identifikasi dan Uji Sensitivitas Staphylococcus aureusterhadap Amoxicillindari Sampel Susu Kambing Peranakan Ettawa (PE) Penderita Mastitis. Jurnal sains veteriner

9. Ika, Hidayati Permata. 2016. Diktat Kuliah Mikrobiologi Dasar. Malang 
10. Suarjana, I Gusti Ketut, I Nengah Kerta Besung, Hapsari Mahatmi, Ketut Tono PG. 2017. Modul Isolasi dan Identifikasi Bakteri. Bali: Universita Udayana

11. Umammamie, Lisa, Rastina, Erina, Reza Ferasyi. 2017. Isolasi dan Identifikasi Escherichia coli DAN Staphylococcus aureus pada keumamah di pasar tradisional lambaroh. Aceh

12. Pujiati. 2015. Buku Ajar Mikrobiologi Umum. Madiun

13. Hemraj, V. 2013. A review on Commonly Used Biochemical Test For Bacteria. India: Departement of Pharmacy, L R Intitute of Pharmacy, Solan (H.P).

14. Yurdakul, N.E, Erginkaya, Unal. 2013. Antibiotic Resistance of Enterococci, Coagulase Negative Staphylococci and Staphylococcus aureuslsolated from Chicken Meat.Czech J. Food Sci. Vol. 31, No.1, hal. 14-19.

15. Anisa, Rahayu. 2015. Media Alternatif untuk Pertumbuhan Bakteri Menggunakan Sumber Karbohidrat yang Berbeda. Surakarta

16. Kurniasih, Nunung, Tina Dewi Rosahdi, Nunik Rahmawati Rahman. 2013. Efektivitas Sari Kedelai Hitam Sebagai Pangan Fungsional. Bandung: UIN Sunan Gunung Djati.

17. Arianti, Widya. 2016. Pertumbuhan Bakteri Escherichia coli dan bacillus subtilis pada Media Singkong dan Ubi jalar Putih Sebagai Substitusi Media NA. Surakarta: Universitas Muhamadiyah.

18. Zubaidah, elok, Eryana Martati, Ampu M Resmanto. 2014. Pertumbuhan Isolat BAL Asal Bekatul dan Probiotik Komersial ( Lactobacillus acidophilus dan Lactobacillus casei ) pada
Media Bekatul dan Susu Skim. Jurnal Bioteknologi dan biosains Indonesia. 